\title{
MetAP2 Inhibitor SDX-7320
}

National Cancer Institute

\section{Source}

National Cancer Institute. MetAP2 Inhibitor SDX-7320. NCI Thesaurus. Code C128030.

A synthetic copolymer-drug conjug ate of a fumagillin-derived methionine aminopeptidase 2 (MetAP2) inhibitor conjug ated to the bio-compatible polymer poly(N(hydroxypropyl)methacrylamide) (HPMA), with potential antineoplastic activity. Upon administration of SDX-7320, the active moiety SDX7539 is released inside the tumor cells. SDX7539 binds to and inhibits MetAP2, which prevents MetAP2-mediated signal transduction pathways and results in tumor cell death. MetAP2, a member of the dimetallohydrolase family upregulated in certain tumor cell types, plays a key role in angiogenesis, proliferation and survival. Polymer conjug ation reduces systemic drug exposure and increases this agent's efficacy as compared to non-polymer conjugates. 